\title{
Assessment of use of public transport in cities by elderly and disabled persons
}

\author{
Katarzyna Solecka \\ ksolecka@pk.edu.pl \\ Tadeusz Kościuszko Cracow University of Technology, Department of Transportation Systems
}

Małgorzata Figura

mfigura85@gmail.com

Tadeusz Kosciuszko Cracow University of Technology, Spatial Management

\begin{abstract}
The public transport system is one of the key factors determining the economic and social development of modern cities, faced with the goal of providing convenient connections between different areas of the functional structure, i.e. ensuring high comfort and short travel time, while minimizing environmental impact. However, it is worth asking: is creating such a transport system possible, does it exclude certain social groups, and is it capable of satisfying the needs of all users? More and more modern planners and transportation engineers are facing this dilemma. According to many scientific publications, universal design is the answer, hence shaping public spaces and the transport systems with awareness of the diversity of the human collectivity in terms of sex, age, physical ability and health condition. Elderly people above 60 years of age and the disabled, who have various types of mental, physical and sensory dysfunctions, are at the greatest risk of social exclusion. These groups of people encounter many architectural and transportation barriers in their daily lives that make it impossible for them to move freely, thus limiting their access to education, employment and culture. Only through analysis of the existing transport system, identification of transportation barriers, and the appropriate decisions to eliminate them can this exclusion be counteracted and a city without barriers be created - a free city where every resident can move easily, whether they are blind, hard of hearing or a wheelchair user. This article defines the concepts of elderly and disabled people and presents the barriers most frequently encountered in city transport systems. Moreover, guidelines for designing a transport system according to the needs of the analyzed group are proposed. The results of survey studies conducted in Oswiecim and Cracow concerning assessment of public transport and its adaptation to elderly and disabled people are a significant part of this article. Results and conclusions obtained from studies can be an inspiration for other cities that want to create a transport system adapted to the needs of the analysed group, however it is also worth remembering that shaping public spaces and transport "for everyone" is only possible by engaging all parties interested in the problem, i.e. above all, elderly and disabled people as well as city authorities, and then making every effort to reach a consensus between these groups.
\end{abstract}

Keywords: transportation system, elderly people, disabled people.

\section{Introduction}

The city of the $21^{\text {st }}$ century is a "product" of civilization, filled with residential development of high and low intensity, modern office and services buildings, supplemented by green public spaces friendly to residents. Moreover, it is an urban unit equipped with a strong, prosperous transport system, which constitutes a key factor determining the city's economic and social development, faced with the goal of providing convenient connections between areas with different purposes, ensuring high comfort and short travel time, while minimizing environmental impact. Today's urban units are unfortunately characterized by many difficulties for elderly and disabled persons who have various types of mental, physical and sensory dysfunctions. These groups of people encounter many architectural and transportation barriers in their daily lives that make it impossible for them to 
move freely, thus limiting their access to education, employment and culture. Thus, modern planners and transport engineers face an enormous challenge: to create a transport system with high accessibility, not excluding certain social groups while satisfying the needs of all users. But is this possible to achieve, and what measures would be appropriate? Can a transport system be fully adapted to the needs of elderly and disabled people?

\section{Elderly and disabled people - basic concepts}

The modern world is inhabited by approximately seven billion people, among them Muslims, Christians, citizens of Spanish, German, Polish origin, black people, people suffering from gigantism, dwarfism, paralysis, blindness or mental impairments. So it is worth thinking about how to correctly define a disabled person. Is such a person an "individual with impaired bodily functions relative to the norm, causing certain limitations and difficulties in fulfilling social roles" [Rzempowska 2011] or a person who has suffered impaired functions of organs, systems or of the entire body as a result of congenital defects or diseases or diseases acquired at different periods of life, which limit their biological and/or social functioning to a varying extent"? [Rzempowska 2011].

Disability is a widespread phenomenon in today's world, and its definition has evolved over the years, changing its original meaning. According to the Resolution of the Sejm of the Republic of Poland dated $1 \mathrm{Au}-$ gust 1997, the "Bill of Rights for Disabled Persons" [World Health Organization 1980], "disabled persons are persons whose physical, mental or intellectual capacity permanently or periodically renders difficult, limits or disables daily life, learning, work and the performance of social roles according to legal and customary norms."

But how to define an elderly person or the aging process? Generally speaking, aging is one of the stages of human life, characterized by a reduction of the body's fitness, independence in living, and a decrease in capacity to adapt to changes that occur. In this process, the risk of health problems is elevated, and general mental and physical condition is deteriorated [Gutowska 2015]. According to the World Health Organization (WHO), aging is a process consisting of individual stages [Gutowska 2015]:

- pre-elderly age $-45-59$ years of age,

- early elderly age -60-74 years of age, people of this age are typically still characterized by full physical and mental capacity,

- late elderly age $-75-89$ years of age, people who require the assistance and care of third parties,

- long-lived age - above 90 years.

According to the definition above, an elderly person will be associated with a person aged 60 or more years, with full or reduced physical capacity, with varying health condition, lifestyle, and requiring care from third parties or not.

\section{The public and individual transport system and elderly and disabled people}

Currently, cities and their spatial management remain unadapted to all groups of users, despite the efforts of city authorities, and this leads to exclusion of individual social groups. Failure to adapt to their needs can be observed in the architecture of buildings (limited access to the interior and limited movement inside them), public spaces (uneven pavements, absence of ramps, lifts) and the public transport system [Misiewicz 2014]. The table below (Table 1) presents the most important difficulties of disabled and elderly people using the transport system. 
Table 1. Transportation difficulties of disabled and elderly people.

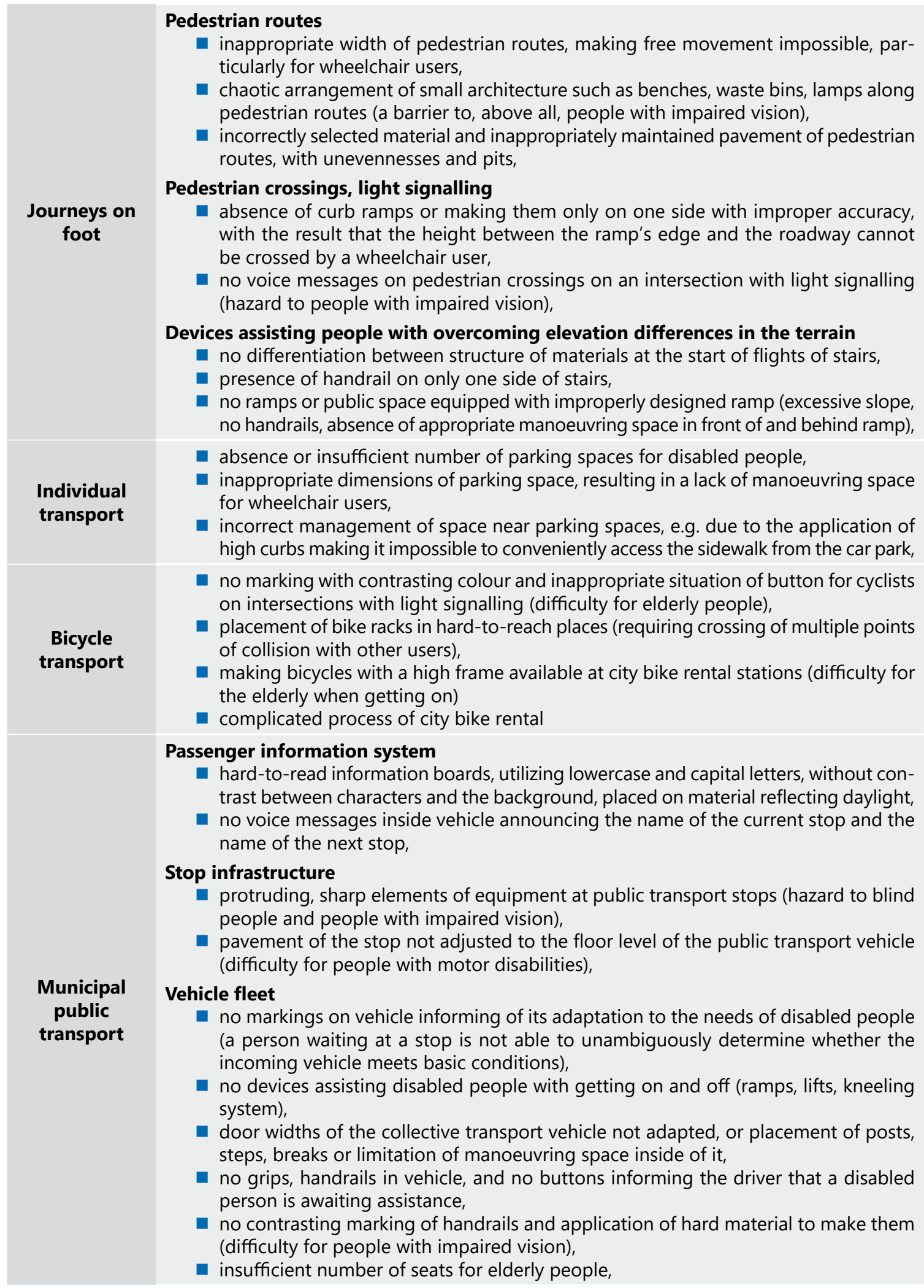




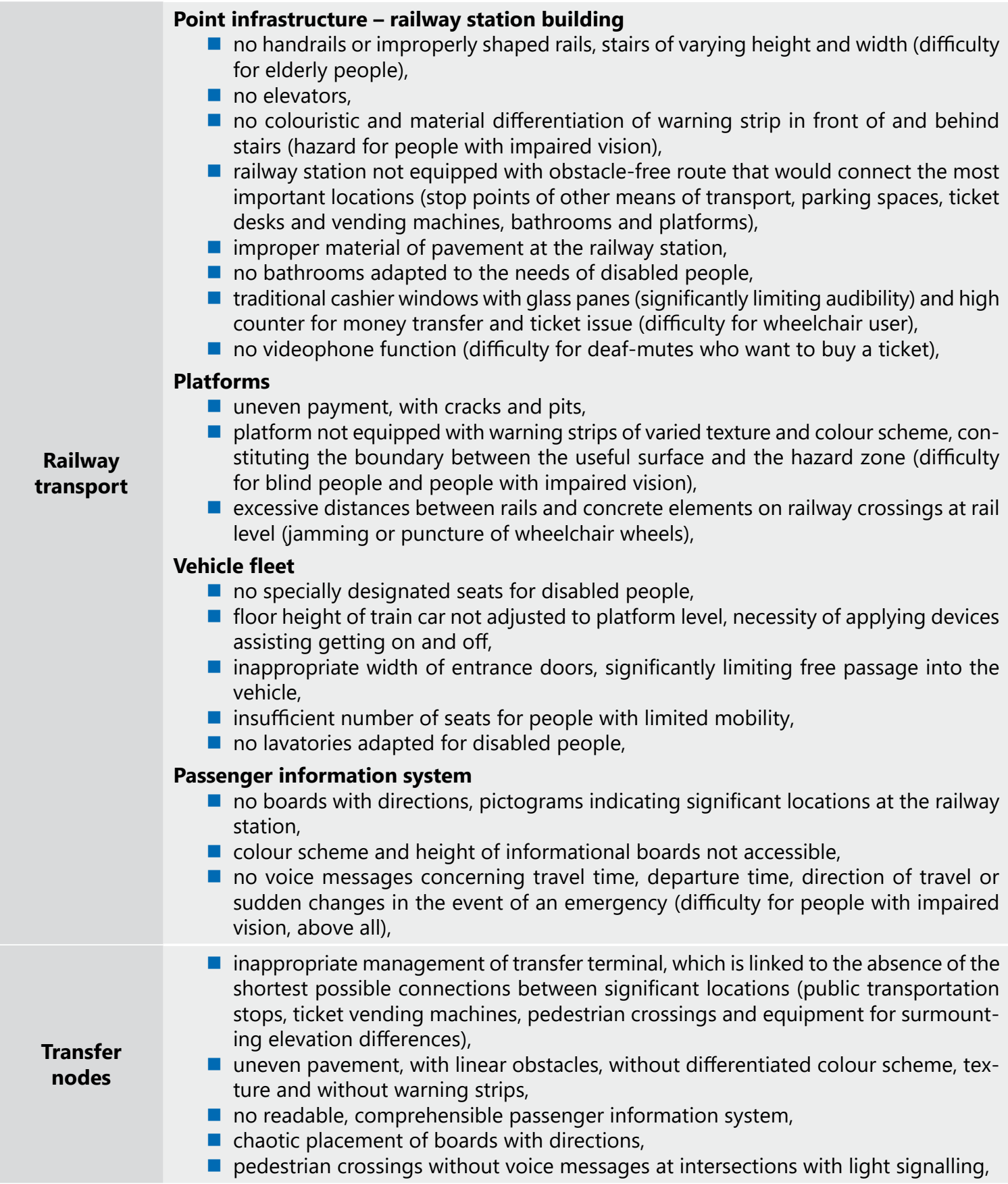

Source: own material based on [Forum Kolejowe - Railway Business Forum 2015, Kowalski 2013, Raczyńska-Buława 2017]

\section{Assessment of the transport system in Oswiecim and Cracow by elderly and disabled people}

The next part of the article presents the examples of two cities in the Malopolskie (Lesser Poland) voivodeship: Cracow, the voivodeship's capital, inhabited by 767,348 people [http://stat.gov.pl] and Oswiecim, the seat of the Oswiecimski poviat's authorities, with a population of 39,972 [http://stat.gov.pl], in the context of assessment 
of the transport system's adjustment to the needs of elderly and disabled people. These cities differ in population and occupied surface area, but they share one common denominator: problems with transport. Like many other cities of the $21^{\text {st }}$ century, these urban units are affected by continuously increasing traffic intensity, low throughput of road systems and the addition of transit traffic to internal traffic. As a consequence of this, there are attempts to limit the traffic of individual vehicles in favour of the development of alternative means of travel.

Both cities are serviced by collective public transport: only bus transport operates in Oswiecim, organized by the Municipal Transportation Company, while in Cracow, transportation is provided by both buses and trams. City transport in both Cracow and Oswiecim realizes connections not only within the respective city's administrative boundaries but also renders services in neighbouring communes. It should be emphasized that Cracow is serviced by 27 tram lines and 161 bus lines [Maderak 2017], while Oswiecim has 27 bus lines, including 9 city buses and 18 suburban buses [Figura 2018]. The difference in the number of offered connections is substantial, but one must take into account that these urban units are characterized by varied levels of economic development, and above all, demand for transport services. But is the transport system in place in these cities adapted to the most demanding group of users - elderly and disabled people? This was the guiding idea behind the survey studies conducted among elderly and disabled people residing in these cities. It is worth noting that the target group (elderly and disabled people) make up a significant percentage of the total number of residents in these cities (Table 2), which will continue to grow over the coming years. Conducted survey studies made it possible to identify the transportation barriers and difficulties encountered by elderly and disable people while travelling on means of public transport.

Table 2. Percentage of elderly and disabled people in the total number of residents in the cities of Cracow and Oswiecim

\section{Oswiecim}

Number of residents

Percentage of elderly people

Percentage of disabled people
38,972 (data from 2016)

$28.49 \%$

$16.65 \%$ (44\% women, $56 \%$ men)

\section{Cracow}

767,348 (data from 2017)

$23.12 \%$

$18.8 \%$ (58\% women, $42 \%$ men)

Source: own material based on [Figura 2018, http://krakow.stat.gov.pl]

The survey study in Oswiecim was conducted using the traditional research technique of direct interview at three locations critical to the city: the transfer node at the PKP Railway Station, one public transport stop (strict city centre) and in the neighbourhood of the largest residential settlement of the urban unit, on a group of 150 elderly and disabled people in 2018 (estimation error 6.7\% at confidence level 0.9). Whereas survey studies in Cracow were conducted in 2017, solely at selected bus and tram stops, on a group of 400 people (estimation error $4.1 \%$ at confidence level 0.9 ).

The most numerous age group among those surveyed both in Cracow and Oswiecim consisted of people between the ages of 60 and 74 (Oswiecim 76\%, Cracow 85\%) (Table 3a). A clear disproportion between the share of surveyed people aged 75 years and above is visible in both cities, which is due to the fact that these people rarely leave home and so use city transport only sporadically. Over $60 \%$ of the Oswiecim respondents and approx. $75 \%$ of Cracow respondents indicate that they have or experience dysfunctions that limit normal functioning and the performance of daily activities to a significant extent (Table 3b). In the capital of the Malopolskie voivodeship, elderly and disabled people most often travel using city transport, and as many as $54 \%$ of those surveyed indicated the tram, and $31 \%$ the bus, as the most frequently used means of transport. Meanwhile, the Oswiecim urban unit is characterized by a different structure, with $66 \%$ of those surveyed travelling most often by foot, and only $17 \%$ using public transport (Table 3c). However, it is worth noting that this disproportion is the result of, above all, the expansiveness of the cities, and thus the distance to destination points. Commercial and services buildings, visits to acquaintances were the most frequently indicated reasons for travel in Oswiecim, whereas in Cracow, those surveyed emphasized that they were taking care of diverse affairs, i.e. matters at local government offices, healthcare points as well as shopping and entertainment. Detailed results 
concerning the age structure, type of impairment, and motivations of those surveyed as well as the division of transportation tasks are presented in the table below (Table 3d).

Table 3. Comparison of obtained results of survey studies with regard to age structure, type of impairment, division of transportation tasks, and motivations for travel in Oswiecim and Cracow

a) Age structure

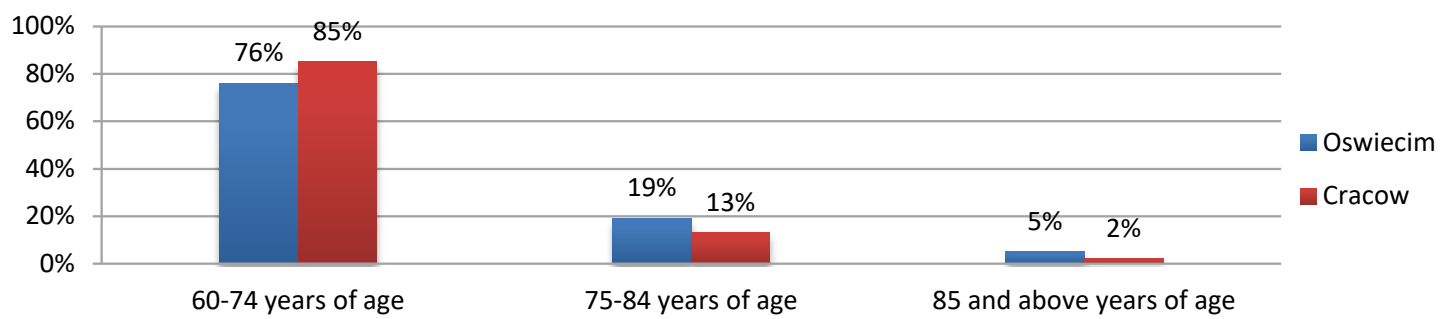

b) Difficulties - type of impairment

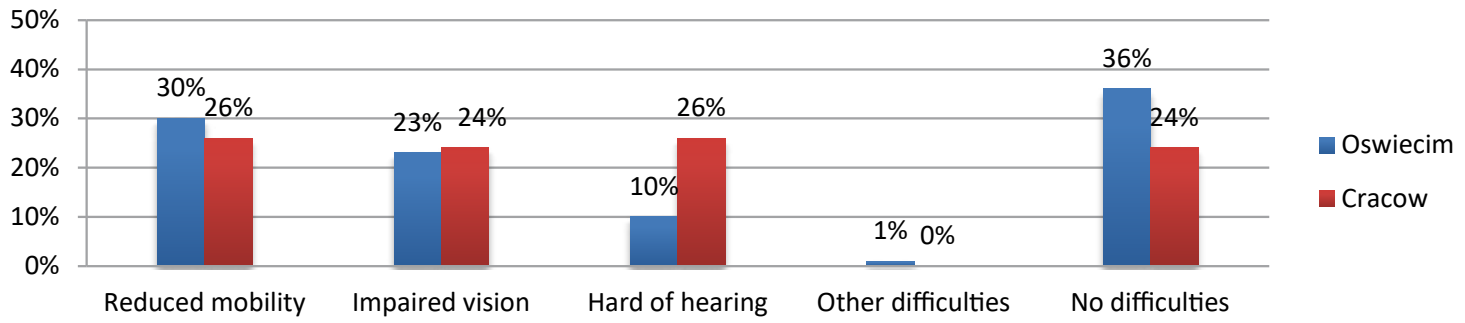

c) Division of transportation tasks

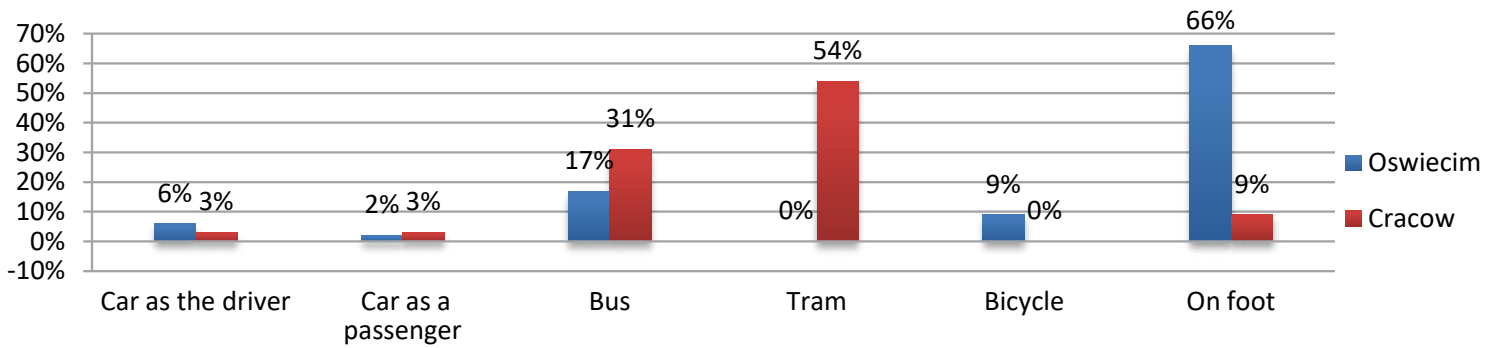

d) Motivations for travel: Oswiecim

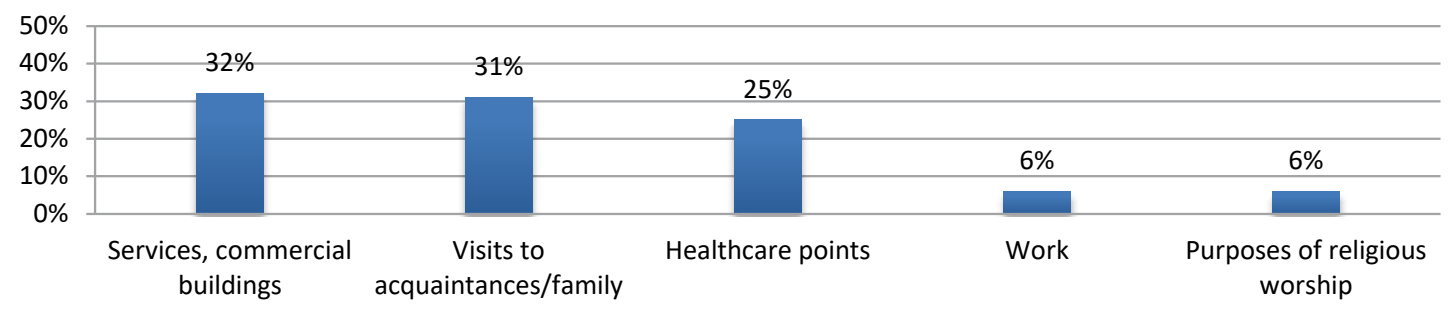

\section{Cracow}

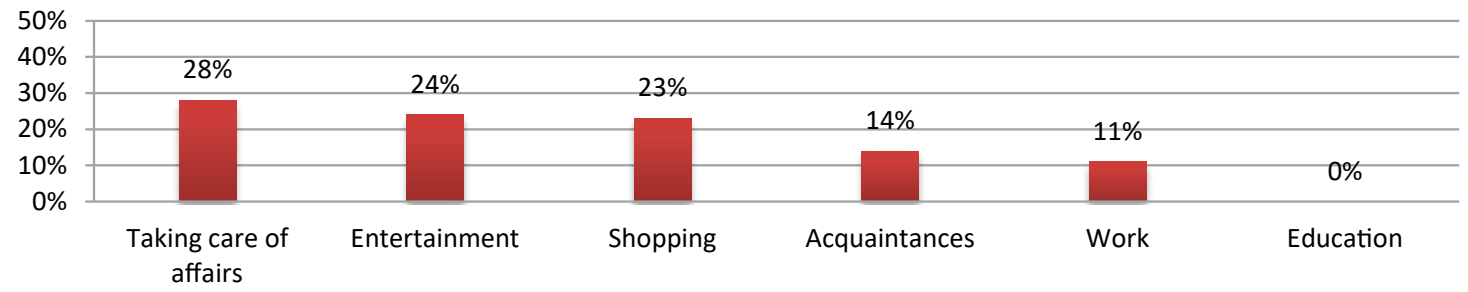

Source: own material based on [Figura 2018, Maderak 2017] 
Moreover, conducted survey studies indicate that the largest group of elderly and disabled people use public transport services several times a month (35\% Oswiecim, 41\% Cracow) (Table 4a). City transport in Oswiecim was assessed at a good level, but only $17 \%$ of those surveyed state that the system fully satisfies their needs (Table 4b). In Cracow however, over half of the respondents assessed the public transport system at a satisfactory, poor or even very poor level (Table 4b). Another key aspect of the conducted studies was determining the apprehensions of elderly and disabled people during travel by means of public transport. In Oswiecim, approx. 60\% of those surveyed do not declare any apprehensions related to use of city transport services. Whereas in Cracow, the majority of respondents have apprehensions about their security during daily travel, difficulty finding a free seat in the vehicle, getting in/out of the vehicle, buying a ticket and swapping to another vehicle (Table 4c).

Table 4. Comparison of obtained results of survey studies with regard to the frequency of using public transport, assessment of public transport, and factors inducing apprehension in Oswiecim and Cracow

a) Frequency of using public transport

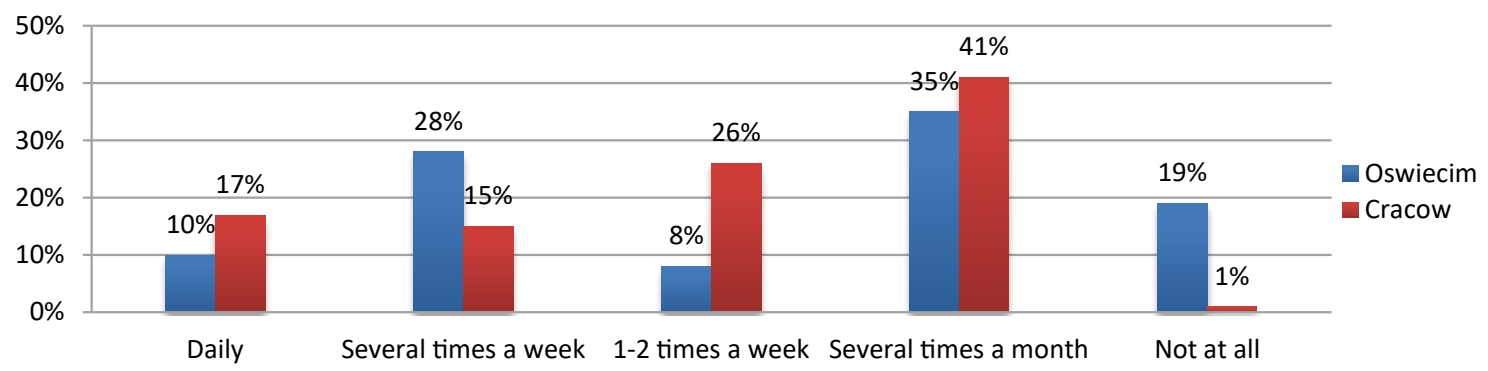

b) Assessment of public transport

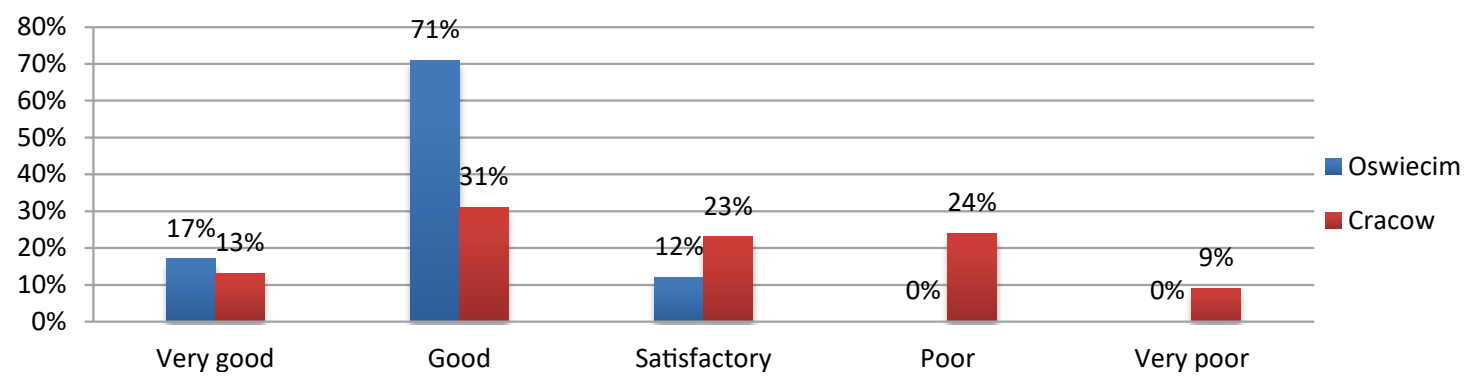

c) Factors inducing apprehension in those surveyed

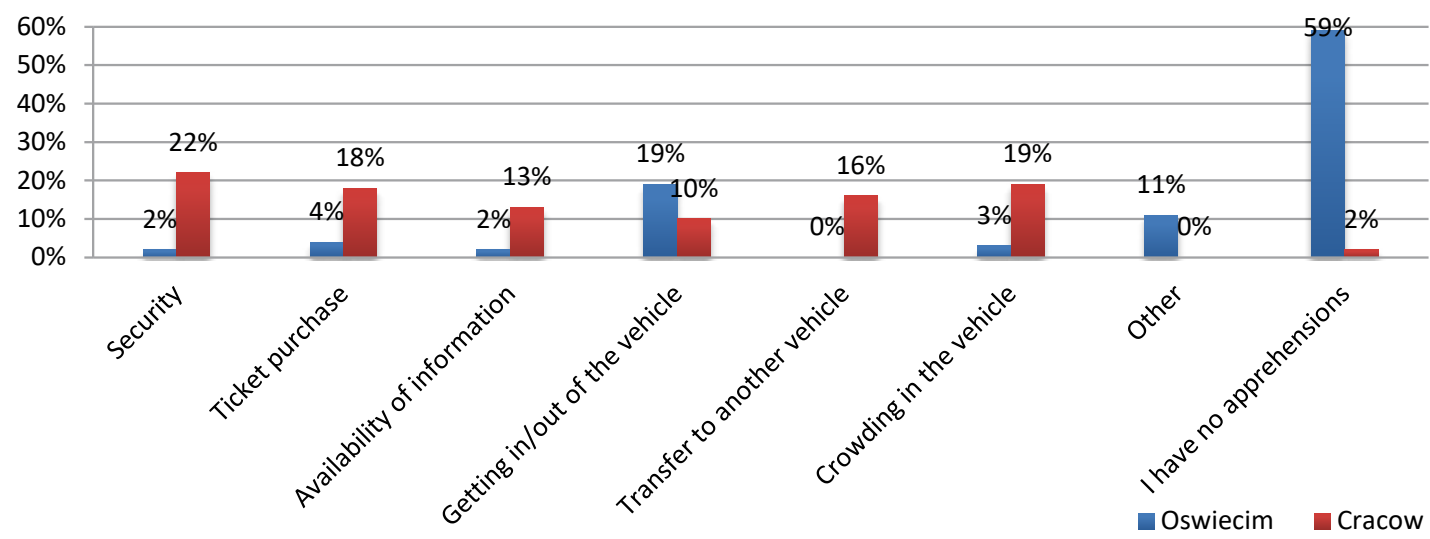


The results of survey studies show that elderly and disabled people who are residents of Oswiecim and Cracow are individuals who exhibit high mobility and eagerly travel both on foot and using city transport. Generally speaking, the target group has a good assessment of the public transport system, but at the same time, perceives elements that require partial or total modernization. To sum up, the most significant difficulties encountered in both cities are the high-floor vehicle fleet, which forces elderly people to exert greater physical effort when getting in or out of the vehicle, and crowding in buses, which leads to an insufficient number of seats for people with limited mobility. In addition, respondents reported their remarks concerning hard-toread line schedules and the absence of voice messages, which is the case in the Oswiecim fleet of vehicles.

\section{Proposals for changes improving travel via public transport for elderly and disabled people in cities}

Analysis of the Oswiecim and Cracow transport systems based on survey studies conducted among elderly and disabled people demonstrated the existence of a number of facilitations as well as a series of elements limiting, rendering difficult or disabling the free movement of elderly and disabled people in the city. Because of this, there is a need for changes to be introduced and transformative measures to be taken to modernize the current public transport system. This subject matter pertains to both larger cities, where the city transport system is highly developed, and smaller urban units, which are characterized by a lower level of development of public transport and a more narrow territorial reach of rendered transport services. So what changes are recommended, what should be done to better adapt the transport system to the needs of elderly and disabled people?

\section{Vehicle fleet}

City transport vehicles play a key role in shaping available collective transportation, and in relation to this, it is recommended to take measures facilitating embarking/disembarking vehicles for people with limited mobility by adapting the floor of a given means of transport to the level of the stop platform and by introducing a lowfloor vehicle fleet. Vehicles adapted to the needs of disabled people should be designated by the international pictogram of a person on a wheelchair, situated on the left or right side on the front of the vehicle and near the main door. Another significant element of the equipment of the city transport vehicle fleet, which should account for the needs of elderly and disabled people, are doors (fig. 1). Vehicles should be equipped with doors of a width above $90 \mathrm{~cm}$, so that a wheelchair user can freely manoeuvre when entering and exiting, and an elderly person with a cane can enter the vehicle freely. Inside vehicles, there should be a specially designated space for a wheelchair user close to the door (fig. 2). An important part of this space is proper marking with a pictogram illustrating the proper wheelchair position as well as handrails, a safety belt and button calling for assistance (fig. 3). In addition, separate seats for people with limited mobility should be separated near the door. Handrails and grips distinguished by a contrasting colour are a significant part of vehicles' equipment. It is important that they do not have any sharp edges and are not made from hard material. Moreover, vehicles should be equipped with buttons informing the driver that a disabled person is getting on or off, on both the inside and outside of the vehicle [Figura 2018].

From the perspective of passenger information, it is recommended for vehicles to be equipped with voice messages informing users of public transport of the name of the current and next stop as well as possibilities for changing the means of transport. It is recommended for messages of this type to also be used in emergencies (failure, change of transport routes, etc.). In such a case, it is proposed for them to be preceded by a special sound signal, preparing passengers for the voice message. Collective transportation vehicles are to be equipped with external sound notices emitting messages about the line number and direction of travel or name of the final stop. Measures of this type substantially improve travel comfort for people with impaired vision and blind people who are waiting for a vehicle.

Another proposed measure is to augment visual information, and so, to introduce additional boards illustrating the entire route of a transport line, with clear indication of the stops and streets on the route. It is proposed to replace traditional information boards with boards in the form of a bead diagram displayed on LCD 
panels, which has a GPS connection, indicating the geographic position of the vehicle, the part of the route already travelled, and the number of stops until the end of the line.

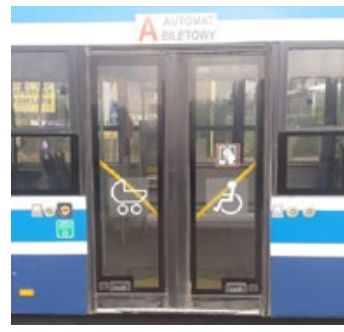

Fig. 1. Bus door equipped with visible pictograms

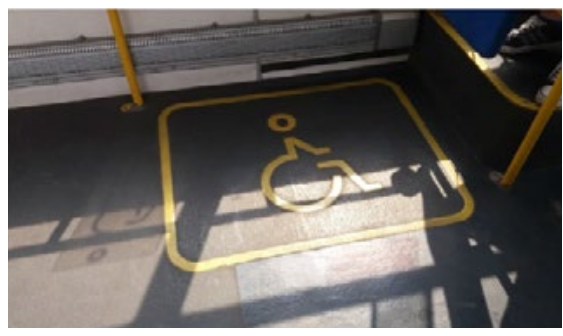

Fig. 2. Examples of spaces intended for wheelchair users in city transport vehicles

Source: [Maderak 2017]

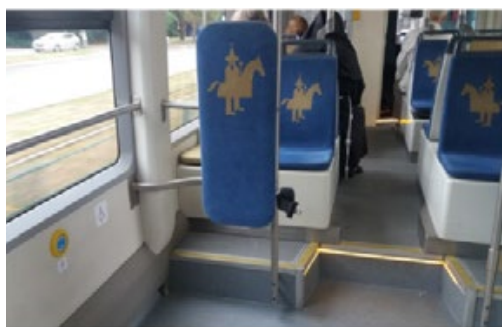

Fig. 3. Safety belts for people on wheelchairs

Source: [Maderak 2017]

It is also worth paying attention to ticket vending machines, which are unfriendly to elderly people in many cities. The font size is too small and unclear, making the information displayed hard to read. In addition, the placement of ticket vending machines in vehicles causes the person operating them to stand in the middle of the corridor and be jostled by other passengers. All of these factors discourage elderly people from using ticket vending machines; furthermore, the target group is very often unable to operate them. In relation to this, it is important to organize special training for elderly people related to the operation of ticket vending machines.

\section{Transport stops and transfer nodes}

Stops and transfer nodes are sites of intensified traffic due to the constant stream of passengers getting on/off public transport vehicles, and where changes of the means of transport take place. Shaping these locations in a way that accounts for the needs of all users poses a great challenge to planners and engineers. Such places must be equipped with the appropriately shaped ramps, elevators or escalators in the case of large elevation differences. The choice of solution is also conditioned by the availability of free land. In the case of small elevation differences, ramps are applied, which should be equipped with handrails, while in the case of significant elevation differences, elevators or platform lifts are applied. It is important to situate the control panel for operating such equipment in their vicinity, with tactile buttons designated using the Braille alphabet as a facility for blind people or people with impaired vision, situated at a height accessible to a wheelchair user [Maderak 2017].

In Poland, the high-floor vehicle fleet is systematically being replaced with low-floor vehicles, and because of this, the side mirrors of buses/trams are lower, which may lead to a person waiting at a public transport stop to be hit by them. Consequently, it is recommended to clearly designate the clearance outline, or the space that is safe for passengers on the stop platform, by means of so-called tactile indicators, which are pavement panels with a contrasting colour scheme (fig. 4). This type of solution will be a facility for people with impaired vision as well as for other users of public transport.

The passenger information system plays a key role in point (stop, station, node) infrastructure, and in relation to this, it should be equipped with the appropriate visual and sound messages. In and around transfer nodes, it is recommended for as much information as possible to be conveyed in the form of pictograms situated in visible locations at the height of a passerby's line of sight. Moreover, besides pictograms, boards with directions indicating access to key locations within the node should be applied. It is important to situate detailed information at forks and intersections of roads - where a decision must be made about the direction of further movement. In addition, boards with directions are to be placed along the most commonly used pedestrian routes, also indicating the name of the buildings to which traffic is being directed (fig. 5).

Moreover, it is important to provide clear information near public transport stops. It is recommended to place boards with the name of the stop on: the front and sides of the stop canopy, as well as boards with transport lines stopping at the stop on the side walls. It is recommended for such boards to be made using black letters on a white background, making them clear and easy to read. It is proposed to equip transport stops with electronic boards with a button in the Braille language initiating a voice message for blind people, which 
will display the time of departure, potential difficulties and delays, adapting the illuminating power of the display to current weather conditions. In addition, it is important for all stops to be equipped with an informational "display case", intended to house easy-to-read line schedules with the appropriate font size as well as a diagram of the transport network. It is proposed to separate free space for wheelchair users and reinforce its presence with an additional horizontal marking at stops characterized by the largest passenger streams in the city, with the remaining stops being the next priority for implementation of this measure. This type of space should be located directly under the informational "display case", which will also allow a wheelchair user or person with impaired vision to get as close as possible to the line schedule. Accenting the presence of such a space with the appropriate pictogram will allow for improvement of "communication" between the disabled person and vehicle driver. A person who requires assistance when getting into a vehicle will be obliged to wait for the bus in this space, thanks to which the vehicle's driver will be aware of the need to provide assistance when approaching the stop, also allowing them to position the vehicle properly in order to minimize the distance between the sidewalk curb and the bus.

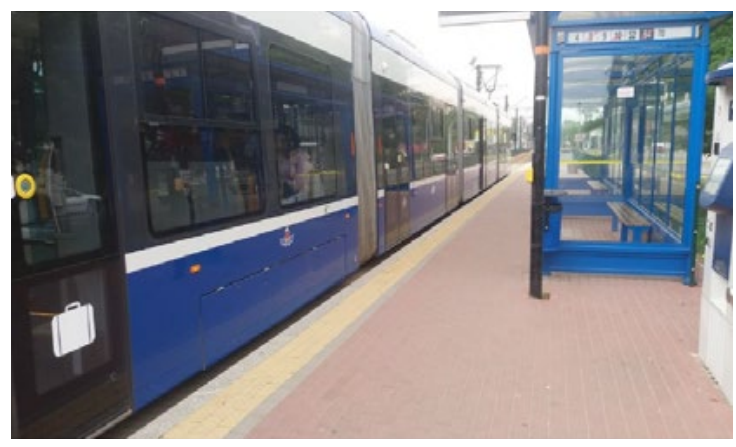

Fig. 4. Pavement panels with yellow tactile indicators at a tram stop in Cracow: Mogilskie roundabout

Source: [Maderak 2017]

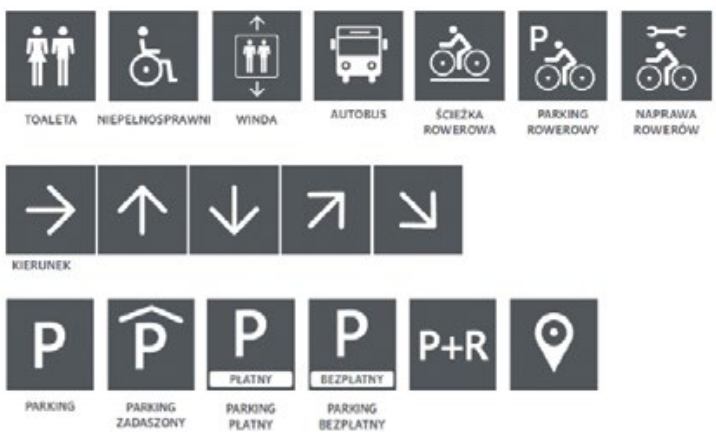

Fig. 5. Pictograms and boards with directions in a transfer node

Source: [CZMUDA Groups Sp. z o.o. 2017]

\section{Pedestrian routes (pavement and small architecture)}

The needs of elderly and disabled people should also be accounted for when designing and managing pedestrian routes, ensuring a space of the appropriate width that is free from obstacles. According to directive [Obwieszczenie Ministra Infrastruktury i Budownictwa z dnia 23 grudnia 2015], a person without any limitations of mobility occupies a width of only $0.75 \mathrm{~m}$. In relation to this, at the design stage, one must keep in mind that people of varying age and different impairments and limitations will be users of this space, requiring much more space for movement in comparison to people without impairments. Ensuring the appropriate width of traffic routes is only one method of improving the comfort of travel for the target group. An additional solution that is proposed is to introduce TGSIs (Tactile Ground Surface Indicators) in cities - a texture system on pedestrian routes having the main goal of directing a person with impaired vision through an obstacle-free route connecting key areas in the urban space. This system would connect pedestrian crossings, transport stops, kiosks where public transport tickets are often purchased, as well as characteristic points in city squares. A solution of this type is analogous to the designation of obstacle-free routes in a railway station. The system will consist of warning, directional and attention textures (fig. 6), perceptible under the foot of a pedestrian, cane of a blind person, and visually due to their contrasting colour.

Another proposed measure is to introduce so-called "rest stops" near pedestrian crossings or long pedestrian routes. These will allow elderly people and people with limited mobility to rest for a while before continuing their journey. In the city centre, it is recommended for such rest stops to be situated at intervals of approx. $50 \mathrm{~m}$ along the routes with the heaviest pedestrian traffic (fig. 7).

Another measure that improves the comfort of travel is to provide separate benches for disabled people, designated by the appropriate pictogram, on both sides of every railway platform in the city. These benches 
will be intended for people with limited mobility (fig. 8). A solution of this type will allow railway personnel to efficiently determine whether any traveller requires assistance with getting on the train, even if no prior notice has been given via telephone [Figura 2018, Obwieszczenie Ministra Infrastruktury i Budownictwa z dnia 23 grudnia 2015].

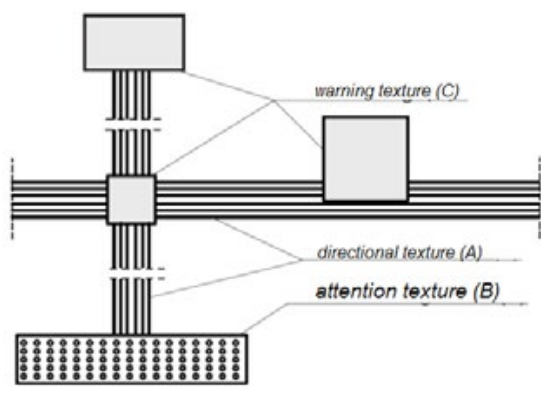

Fig. 6. Elements of the texture system on pedestrian routes

Source: [Wysocki 2013]

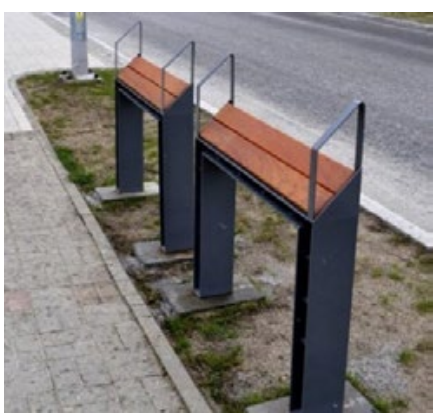

Fig. 7. City rest stops

Source: [UM Gdynia, 2017]

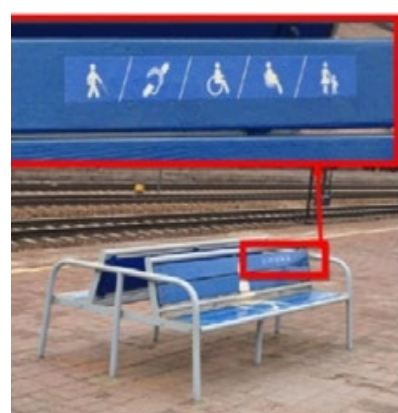

Fig. 8. Benches intended for disabled people (SKM Gdansk) Source: [Ciszewska-Kulwińska 2016]

Furthermore, additional measures improving travel around the city for elderly and disabled people are:

Adapting the websites of the organizers of collective transportation to the needs of hard-of-hearing people and people with impaired vision

- Creating an application - travel without barriers - which provides information on available city transport and rail transport connections accounting for the user's individual needs, operating according to the example of the VBB program, which searches for connections in Berlin and Brandenburg.

\section{Summary}

The examples of Oswiecim and Cracow show that elderly and disabled people encounter various barriers and difficulties in day-to-day travel. The absence of ramps, chaotic placement of small architecture on pedestrian routes, high-floor buses, the absence of devices assisting a wheelchair user in embarking/disembarking city transport vehicles are just some of them. One must be conscious of the fact that the available transport system is transportation for everyone, for a fifteen-year-old boy, a thirty-year-old pregnant woman, a fifty-year-old man with impaired vision and a sixty-year-old woman on a wheelchair, and if it is designed with the needs of the most demanding users in mind, the comfort and satisfaction of other users of the public transport system will also be improved, substantially raising the quality of public transport services in users' eyes. The key is to be aware of the problem posed by transportation barriers and then to take measures contributing to their elimination. The final effect of these measures will be to the satisfaction of all residents; and satisfied residents are a hallmark of a well-functioning city as well as a stimulus for undertaking further development actions.

\section{References}

[1] Ciszewska-Kulwińska E., 2016; Analiza infrastrukturalnych usprawnień dla niepełnosprawnych na przykładzie przystanków SKM w Gdańsku, III Krakowska Ogólnopolska Konferencja Naukowa Transportu "KOKONAT", Kraków.

[2] CZMUDA Groups Sp. z o.o., 2017; Wspólne standardy wizualne i funkcjonalne w zakresie zagospodarowania przestrzeni publicznej budowanych i modernizowanych węzłów integracyjnych na Obszarze Metropolitalnym Gdańsk-Gdynia-Sopot w tym zakresie elementów tzw. „małej architektury” i oznakowania, Obszar Metropolitalny Gdańsk Gdynia Sopot.

[3] Figura M., 2018: Dostępność transportu publicznego i indywidualnego dla osób starszych i niepełnosprawnych w Oświęcimiu, praca magisterska, Kraków. 
[4] Forum Kolejowe - Railway Business Forum, 2015: Biała Księga Niepełnosprawni a transport kolejowy - aktualny stan dostępności kolei dla osób o ograniczonej możliwości poruszania się, Warszawa.

[5] Gutowska A., 2015: Nie(pełnosprawność) starość - przyczyny, uwarunkowania, wsparcie, Interdyscyplinarne Konteksty Pedagogiki Specjalnej, Poznań, nr 8.

[6] http://stat.gov.pl (accessed 15.04.2018)

[7] International Classification of Impairments, Disabilities and Handicaps, WHO, Genewa 1980, Lancet 1964: 1, 1117-1120.

[8] Kowalski K., 2013: Planowanie dostępności - polskie uwarunkowania prawne i praktyka, Niepełnosprawność - Zagadnienia, Problemy, Rozwiązania, Warszawa, tom I/2013, nr 6, 71-99.

[9] Maderak D., 2017: Ocena miejskiego systemu transportu publicznego w Krakowie przez osoby starsze, praca magisterska, Kraków.

[10] Misiewicz M., 2014: Miasto przyjazne niepełnosprawnym?, Niepełnosprawność - Zagadnienia, Problemy, Rozwiązania, tom II/2014, $\mathrm{nr} 11,80-94$

[11] Obwieszczenie Ministra Infrastruktury i Budownictwa z dnia 23 grudnia 2015 r. w sprawie ogłoszenia jednolitego tekstu rozporządzenia Ministra Transportu i Gospodarki Morskiej w sprawie warunków technicznych, jakim powinny odpowiadać drogi publiczne i ich usytuowanie (Dz.U.2016 poz.124).

[12] Raczyńska-Buława E., 2017: Osoby niepełnosprawne w systemie transportu publicznego, TTS Technika Transportu Szynowego, nr 5, 16-26.

[13] Rzempowska J., 2011: Socjometryczne aspekty funkcjonowania młodych osób niepełnosprawnych w środowisku wiejskim, Uniwersytet Medyczny im. Karola Marcinkowskiego w Poznaniu, Rozprawa doktorska, Poznań.

[14] UM Gdynia, http://ladnydom.pl/wnetrza/7,101999,21688401,w-gdyni-pojawily-sie-nowe-meble-miejskie-przysiadaki. html (accessed 13.04.2018)

[15] Wysocki M., 2013: Standardy dostępności dla Miasta Gdynia, Gdynia. 